\title{
Evaluation of Linear Accelerator (Linac)-Based Stereotactic Radiosurgery (Srs) for The Treatment of Craniopharyngiomas
}

\author{
Selcuk DEMIRAL ${ }^{1}$, Murat BEYZADEOGLU ${ }^{1}$, Omer SAGER ${ }^{1}$, Ferrat DINCOGLAN ${ }^{1}$, Hakan GAMSIZ ${ }^{1}$, \\ Bora UYSAL ${ }^{1}$, Kaan OYSUL ${ }^{1}$, Esin GUNDEM ${ }^{1}$, Bahar DIRICAN ${ }^{1}$, Sait SIRIN ${ }^{2}$ \\ ${ }^{1}$ Gulhane Military Medical Academy, Department of Radiation Oncology \\ ${ }^{2}$ Gulhane Military Medical Academy, Department of Neurosurgery, Ankara, TURKEY
}

\begin{abstract}
Although benign histologically, craniopharyngiomas may display clinically malignant behavior with a strong propensity for recurrence. Contemporary therapeutic approaches for craniopharyngiomas include stereotactic irradiation in the form of Stereotactic Radiosurgery (SRS) or Fractionated Stereotactic Radiation Therapy (FSRT) as part of multimodality treatment particularly when complete surgical removal is not feasible. In this study, we evaluate the use of Linear Accelerator (LINAC)-based SRS in the multidisciplinary management of patients with craniopharyngiomas. Between July 1998 and July 2013, 20 patients (11 male, 9 female) with residual or recurrent craniopharyngiomas were treated using LINAC-based SRS at Department of Radiation Oncology, Gulhane Military Medical Academy. Median age was 37 (9-69) years. Median tumor volume was 1.1 (0.9-6.9) cc. Median dose was 13 Gy (range: 10-16 Gy) prescribed to the $80 \%-95 \%$ isodose line encompassing the target volume. Median follow-up time was 47 (7-93) months. Overall local control rate was $88 \%$ at 1 year, $79 \%$ at 3 years and $66 \%$ at 5 years. Three and 5 -year progression free survival rates were $95 \%$ and $91 \%$ whereras 3 and 5 -year overall survival rates were $94 \%$ and $88 \%$, respectively. Our study supports the usage of LINAC-based SRS as a safe and effective management strategy for patients with recurrent or residual craniopharyngiomas.
\end{abstract}

Keywords: Craniopharyngioma, Stereotactic Radiosurgery (SRS), Linear Accelerator (LINAC)

\section{ÖZET}

Kraniofarinjiyom Tedavisinde Lineer Akseleratör Tabanlı Stereotaktik Radyocerrahinin Değerlendirilmesi

Kraniofarinjiyomlar histolojik olarak benign olsalar da rekürrens için güçlü bir eğilimle klinik olarak malign davranış sergileyebilirler. Güncel terapötik yaklaşımlar özellikle tam cerrahi rezeksiyonun uygun olmadığı durumlarda multimodal tedavinin bir parçası olarak stereotaktik radyocerrahi ya da fraksiyone stereotaktik radyoterapi şeklinde stereotaktik ışın tedavisini içermektedir. Bu çalışmada kraniofarinjiyomların multidisipliner manajmanında lineer akseleratör tabanı stereotaktik radyocerrahinin kullanımı değerlendirimektedir. Temmuz 1998 ile Temmuz 2013 arasında rezidüel ya da rekürren kraniofarinjiyomlu 20 hasta (11 erkek, 9 kadın) Gülhane Askeri Tıp Akademisi Radyasyon Onkolojisi Departmanında lineer akseleratör tabanlı stereotaktik radyocerrahi kullanılarak tedavi edilmiştir. Medyan yaş 37 (9-69) idi. Medyan tümör volümü 1.1 (0.9-6.9) cc idi. Hedef volümü saran \%80-\%95 izodoz çizgisine preskribe edilen medyan doz 13 Gy (ranj: 10-16 Gy) idi. Medyan takip süresi 47 (7-93) ay idi. Lokal kontrol oranı 1. yılda \%88, 3. yılda \%79, 5. yılda \%66 idi. 3 ve 5 ylllık progresyonsuz sağkalım oranları sırasıyla \%95 ve \%91 iken 3 ve 5 yıllık toplam sağkalım oranları sırasıyla \%94 ve \%88 idi. Çalışmamız rekürren veya rezidüel kraniofarinjiyomlu hastalar için lineer akseleratör tabanlı stereotaktik radyocerrahinin güvenli ve etkin bir manajman stratejisi olarak kullanımın desteklemektedir.

Anahtar Kelimeler: Kraniofarinjiyoma, Stereotaktik Radyocerrahi, Lineer Akseleratör 


\section{INTRODUCTION}

Craniopharyngiomas are rare, dysontogenic tumors of the sellar region. These benign tumors typically arise in the pituitary stalk, and are also referred to as "Rathke pouch tumors" or "hypophyseal duct tumors". They follow a bimodal age distribution with one peak in children at 5-14 years and a second peak in adults at 50-74 years. ${ }^{1}$

Craniopharyngiomas may have solid, cystic, mixed solid and cystic, or calcified components in their structural composition. Depending on their location, size, growth rate, and relation with adjacent structures; pituitary hormone deficiency, visual field loss, obstructive hydrocephalus and extraocular cranial nerve palsies may occur. ${ }^{2,3}$ Hemianopsia and papilledema are the probable visual field defects which could be the presenting symptoms in patients with tumors compressing the optic chiasm. ${ }^{4}$

Optimal management of craniopharyngiomas remains a major therapeutic challange. Aggressive surgery with the goal of complete and immediate tumor elimination may be attempted. ${ }^{5-9}$ However, depending on the primary location and extension pattern of the tumor, complete excision may not be feasible in some patients due to the potential of substantial morbidity. To treat these patients with tumors unsuitable for gross total resection, a more conservative approach including planned limited surgery followed by radiation therapy may be used to reduce the mass effect on the optic apparatus while avoiding endocrinologic and behavioral morbidity associated with aggressive surgery. ${ }^{10-12}$

A significant improvement has been achieved in the precision and conformity of radiation therapy in recent years thanks to the major advances in neuroimaging and radiation treatment planning software. Stereotactic irradiation in the form of either Stereotactic Radiosurgery (SRS) or Fractionated Stereotactic Radiation Therapy (FSRT) is being increasingly utilized recently in the management of craniopharyngiomas to improve treatment outcomes. ${ }^{13-16}$

In this study, we evaluate the use of Linear Accelerator (LINAC)-based SRS in the management of craniopharyngiomas and report our single-center experience.

\section{PATIENTS AND METHODS}

Between July 1998 and July 2013, 20 patients (11 male, 9 female) with craniopharyngiomas referred to the Department of Radiation Oncology, Gulhane Mil-

\begin{tabular}{|ll|}
\hline Table 1. Patient and treatment characteristics \\
\hline Sex & 11 \\
Male & 9 \\
Female & 37 (9-69) \\
Median age (range) & 3 \\
Complete excision & 15 \\
Incomplete excision & 2 \\
Biopsy & \\
Tumour position & 2 \\
$\quad$ Intrasellar & 6 \\
$\quad$ Suprasellar & 12 \\
$\quad$ Both & 10 \\
Solid & 3 \\
Cystic & 7 \\
Mix & \\
Gross tumor volume (GTV) & 1.1 cc \\
$\quad$ Median & $(0.9-6.9)$ cc \\
Range & 13 Gy (range: 10-16 Gy) \\
Dose prescription & $80 \%-95 \%$ \\
Isodose line & \\
Number of treated patients & 3 \\
For progression after surgery & 10 \\
For residual disease just after & \\
surgery & \\
For recurrent disease after & \\
second or more surgery & \\
\hline
\end{tabular}

itary Medical Academy were treated using LINACbased SRS. The indication for SRS was the presence of either residual or recurrent tumor after surgery. Patient and treatment characteristics are shown in Table 1.

Before SRS, all patients had undergone surgery. Fifteen patients had one surgical resection and five had two or more surgical interventions. Ten patients underwent immediate SRS after conservative surgery while seven patients were treated after second or subsequent surgery for disease progression. For 3 patients allocated to follow-up after prior surgery, radiosurgical treatment was performed at the time of documented disease progression. Informed consents of all patients were taken before treatment. Median age was 37 years (range: 9-69 years). Four patients were children ( $<16$ years old). Ten tumors were classified as being solid, 3 as cystic and 7 as mixed. Mean tumor diameter was $13.9 \mathrm{~mm}$ and median tumor volume was $1.1 \mathrm{cc}$ (range: 0.9-6.9 cc).

Details of the SRS procedure was described previ- 


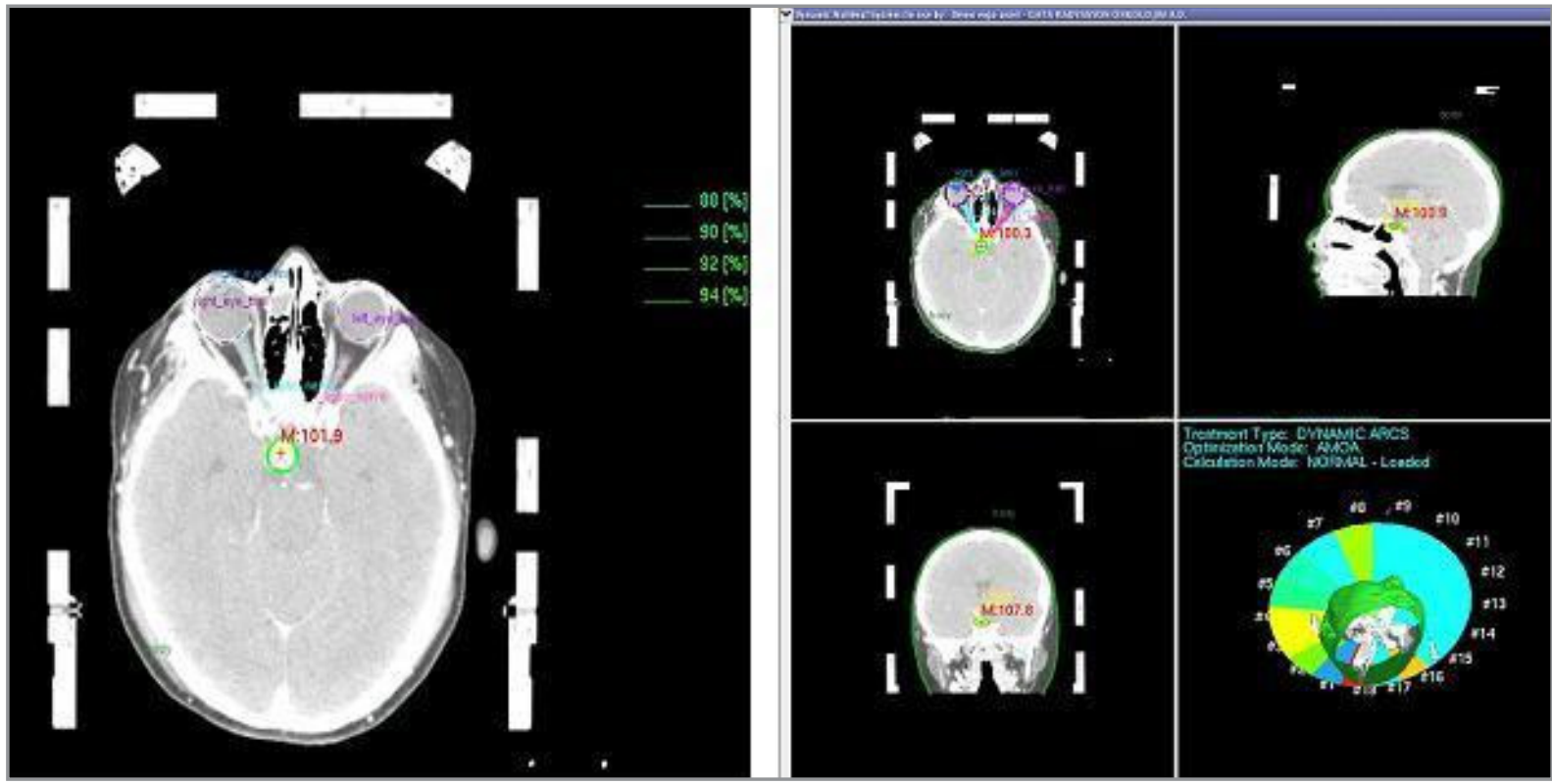

Figure 1. Treatment planning images of a patient with craniopharyngioma in axial, coronal, sagittal, and 3-D planes in ERGO planning system

ously. ${ }^{17-21}$ All patients underwent high-precision SRS using a LINAC with 6-MV photons. For the first 10 years (1998-2008), XKnife-3 (Radionics, Boston, MA, USA) radiosurgery planning system was used in SRS planning and cone-based SRS was delivered by LINAC SL-25 with circular cones (Elekta, UK). Whilst, after 2008, Volumetric Modulated Arc Radiosurgery has been started to be delivered by LINAC Synergy (Elekta, UK) with $3 \mathrm{~mm}$-thickness head-on micro-multileaf collimator (mMLC) with the introduction of mMLC-based intensity modulated SRS using ERGO ++ (CMS, Elekta, UK) radiosurgery planning system at our department. Leksell and Brown-Roberts-Wells (BRW) frames were used in mMLC-based and cone-based SRS applications, respectively. On the day of SRS, the stereotactic frame was secured with 4 pins to the patient's skull under local anesthesia. Following rigid immobilization with the stereotactic head frame, contrast enhanced Computed Tomography (CT) images with $1.25 \mathrm{~mm}$ slice thickness were acquired by CT-simulator (GE Lightspeed RT, GE Healthcare, Chalfont St. Giles, UK). Acquired images were sent to the contouring workstation via network. Advantage SimMD simulation and localization software (Advantage SimMD, GE, UK) was used for contouring the target volume and critical structures. The visible postoperative residual lesion including solid component was outlined as the gross tumor volume (GTV) on the MRI. Planning tar- get volume (PTV) was considered the same as GTV. Coronal and sagittal images were used in addition to axial images along with planning $\mathrm{CT}$ and Magnetic Resonance Imaging (MRI) fusion to improve target and organ-at-risk (OAR) contouring.

After completion of delineation procedure, structure sets including the target and OARs such as the brainstem, optic apparatus, cochlea and the hypothalamus were transferred to the treatment planning system (ERGO++ planning system, Elekta or XKnife-3, Radionics) for cone-based or mMLC-based SRS treatment planning.

Arc Modulation Optimization Algorithm (AMOA) was used to avoid violation of OAR dose limits while improving dose homogeneity within the target volume in the mMLC-based intensity modulated SRS plans using the volumetric-modulated arc therapy (VMAT) technique. Figure 1 shows treatment planning images of a patient with craniopharyngioma in axial, coronal, sagittal, and 3-D planes in ERGO planning system.

Either a single 360-degree arc, double 360-degree arcs, or five 180-degree arcs was selected for each patient in SRS planning to achieve the best treatment plan in terms of target coverage and OAR sparing. Median dose was 13 Gy (range: 10-16 Gy) prescribed to the $80 \%-95 \%$ isodose line encompassing the target volume. The dose to the optic apparatus was limited to less than $8 \mathrm{~Gy}$. Image-guided radiation therapy 


\begin{tabular}{|lcc|}
\hline $\begin{array}{l}\text { Table 2. Local control (LC), Overall survival (OS), Progres- } \\
\text { sion-free survival (PFS) after SRS }\end{array}$ \\
\hline & 3 year & 5 year \\
\hline LC \% & 79 & 66 \\
OS \% & 94 & 88 \\
PFS \% & 95 & 91 \\
\hline
\end{tabular}

(IGRT) techniques including kilovoltage Cone Beam $\mathrm{CT}(\mathrm{kV}-\mathrm{CBCT})$ and X-ray Volumetric Imaging (XVI, Elekta, UK) system was used in all patients undergoing mMLC-based SRS for isocenter and setup verification.

After SRS procedure was completed, follow-up visits were scheduled for every patient at 3-month intervals for the first year, at 6-month intervals for the second year, and annually afterwards. Clinical examination, visual field testing, detailed neurological evaluation and neuroimaging with contrast-enhanced MRI was performed routinely at each follow-up visit. Pituitary function was assessed by basal hormonal assessment and vision was assessed by serial ophthalmological examinations. Common Toxicity Criteria Version 4.0 was used in toxicity assessment.

Local control was defined as no solid or cystic tumor enlargement or presence of tumor downsizing on follow-up neuroimaging and evaluation of local tumor control was based on the comparison of pre-SRS and post-SRS tumor size measurements. Progression-free survival was defined as the time from the first day of radiosurgery to the time of documented solid tumor progression. All patients were instructed to inform the treating physician about any unexpected neurological deterioration notwithstanding the follow-up schedule.

\section{RESULTS}

Nineteen patients (95\%) out of the total 20 patients were alive at the time of analysis. One patient died 87 months after SRS due to disease progression. Of the 10 patients with solid tumors, complete response was achieved in $3(30 \%), \geq 50 \%$ downsizing in $4(40 \%),<$ $50 \%$ downsizing in $2(20 \%)$ and upsizing in $1(10 \%)$ patient. Of the 7 patients with mixed tumors, $\geq 50 \%$ downsizing was achieved in $2(28.5 \%),<50 \%$ downsizing in $3(42.8 \%)$ and upsizing in $1(14.2 \%)$ patient. One of the cystic tumors $(33.3 \%)$ showed $<50 \%$ downsizing while the other two showed cystic progression. The overall local control rate was $88 \%$ at 1 year, $79 \%$ at 3 years and $66 \%$ at 5 years. 3 and 5 -year progression free survival (PFS) rates were $95 \%$ and $91 \%, 3$ and 5-year overall survival rates were $94 \%$ and $88 \%$, respectively. LC, PFS, and OS outcomes are shown in Table 2.

Hormonal functions improved in 1 out of the 8 patients suffering from anterior lobe hypopituitarism 21 months after SRS, and remained stable for the 4 patients with panhypopituitarism and 3 patients with normal pituitary function.

Visual deterioration developed in 2 out of the 7 patients presenting with visual-field defects due to disease progression despite treatment. Visual function improvement with tumor downsizing was observed in 1 patient. Homonymous hemianopsia due to progressive disease developed in 3 of the 13 patients with normal visual fields. Table 3 shows endocrine and visual function status of the patients after completion of SRS.

Acute toxicity in the form of nausea and headache was observed in five patients out of total 20 patients and resolved with medical therapy whilst five patients had progressive visual disturbance at 6 to 12 months

Table 3. Endocrine and visual function outcomes after SRS

\begin{tabular}{lllll|} 
& Pre-SRS & \multicolumn{2}{c}{ Post-SRS } \\
\cline { 3 - 4 } & & Improved & Unchanged & Worse \\
\hline Visual Function & 13 & 0 & 10 & 3 \\
Normal & 7 & 1 & 4 & 2 \\
Visual field defect & & & 3 & 1 \\
Hormonal Function & 5 & 0 & 7 & 1 \\
Normal & 9 & 1 & 4 & 2 \\
Anterior lobe hypopituitarism & 6 & 0 & & \\
Panhypopituitarism & & & & \\
\end{tabular}


after SRS with documented cystic enlargement on MRI.

Hypothalamic dysfunction developed in one patient. Hormon profile of hypopituitarism worsened in 3 patients presenting with initial hypopituitarism before SRS. No clinically apparent neurocognitive dysfunction, cerebrovascular accidents, second malignancy and radionecrosis was detected in the whole studied group.

\section{DISCUSSION}

While surgical resection is the mainstay of treatment for patients with craniopharyngiomas, local recurrence rates after surgery alone are considerably high even after gross total resection. ${ }^{8,9}$ Critical tumor location frequently precludes optimal surgical management. In the context of significant morbidity of the extensive surgery, limited surgery followed by complementary adjuvant radiotherapy has been suggested in order to minimize surgery-related side effects. ${ }^{10-12}$ Higher morbidity and mortality with lower cure rates is of concern when repeat surgery is done for recurrent craniopharyngiomas. ${ }^{9,22-24}$

Therapeutic options other than surgery alone for residual and recurrent craniopharyngiomas include combined modalities of intracavitary chemotherapy and radiotherapy in the forms of conformal fractionated radiotherapy, Intensity Modulated Radiation Therapy (IMRT), stereotactic radiosurgery, stereotactic radiotherapy, conventional fractionated radiotherapy or intracavitary brachytherapy. In radiosurgical management of craniopharyngiomas, selection of tumor margin dose is determined by the tumor volume and its proximity to critical structures. SRS dose may profoundly affect treatment outcomes in terms of local control and procedure-related toxicity. ${ }^{25,26}$ Small-volume craniopharyngiomas respond favorably whereas tumors of any size in the close vicinity of optic apparatus pose a significant risk of unfavorable treatment-related toxicity despite the established sharp dose gradient outside the target volume.

In the study by Jeon et al, 50 patients treated with Fractionated Steretactic Radiation Therapy (FSRT) and Gamma Knife Radiosurgery (GKRS) for recurrent or residual craniopharyngioma, therapeutic efficacies of FSRT and GKRS were compared and no difference between two treatment techniques was noted in terms of therapeutic efficacy. ${ }^{27}$

In the study by Combs et al., 40 craniopharyngioma patients treated with fractionated radiotherapy alone resulted in five and ten-year LC of $100 \%$ and 5 and 10 -year OS of $97 \%$ and $89 \%$ respectively. ${ }^{16}$

In a report by Minniti et al., FSRT used as single treatment modality conferred tumor control rates of $69 \%, 3$ and 5-year PFS of $97 \%$ and $92 \%$, and 3 and 5 -year survival rate of $100 \%$ at a median follow-up time of 57 months. ${ }^{14}$

Radiosurgery has been used as a viable therapeutic option in the management of craniopharyngiomas with promising treatment outcomes. ${ }^{13-16,26,28-32}$ In a literature review of 10 studies evaluating Gamma Knife radiosurgery in the management of children and adult craniopharyngiomas, tumor control rates differed in cystic, solid and mixed tumor types with overall tumor control being $75 \% .{ }^{32}$ Corresponding control rates for solid, cystic, and mixed tumors were $90 \%, 80 \%$, and $59 \%$, respectively with radiosurgery-related overall morbidity of $4 \%$ and an overall mortality rate of $0.5 \%{ }^{31}$

A retrospective review by Lee et al. in which 16 patients with residual or recurrent craniopharyngiomas were treated with multisession CyberKnife SRS revealed control and shrinkage of the tumor in $91 \%$ of the 11 patients without any deterioration in neuroendocrine or visual function at a mean follow-up period of 15.4 months. ${ }^{32}$

In the study by Niranjan et al., 46 patients with residual or recurrent craniopharyngiomas underwent Gamma Knife SRS. ${ }^{13}$ Overall LC rate (for both solid tumor and cyst control) was $91 \%, 81 \%$, and $68 \%$ at 1 , 3 , and 5 years, respectively. No patients with normal pituitary function developed hypopopituitarism after SRS. Two patients developed homonymous hemianopsia owing to tumor progression after SRS.

In a study by Chung et al. reporting 31 patients with craniopharyngioma, tumor control rate was $87 \%$ with a prescription dose of 9.5 to 16 Gy with $84 \%$ of patients having fair to excellent clinical outcomes in an average follow-up period of 36 months. ${ }^{28}$ Only one patient experienced mild visual field restriction. There weren't any signs and symptoms of additional neurological deterioration or endocrinological impairment ascribed to treatment and no treatment-related mortality was reported.

In the study by Lee et al. ${ }^{32}$, no visual or neuroendocrine complication was noted whereas Ulfarsson et al. ${ }^{30}$ reported visual deterioration in 8 patients and pituriary deficiencies in 4 patients. Chung et al. ${ }^{28} \mathrm{re}$ ported mild restriction in visual field in 1 patient. In our study, we achieved an average local tumor con- 
trol rate of $87.5 \%$ for solid craniopharyngiomas in consistency with the study by Gopalan et al. reporting a local control rate of $90 \%$ for solid craniopharyngiomas undergoing Gamma-Knife surgery, suggesting that the compositional structure of craniopharyngiomas such as solid, cystic, mixed solid and cystic, or calcified may influence the treatment outcomes. ${ }^{31}$ In our study, 3 and 5-year progression free survival (PFS) rates were 95\% and 91\%,3 and 5-year overall survival rates were $94 \%$ and $88 \%$, respectively.

In our study, mild acute toxicity (nausea, headache) was observed in 5 patients which resolved with medical intervention. Five patients had progressive visual disturbance at 6 to 12 months after SRS and cystic enlargement was documented on MRI of these patients. Hypothalamic dysfunction developed in one patient. Hypopituitarism worsened in 3 patients who presented with hypopituitarism before SRS. No clinically apparent neurocognitive dysfunction, cerebrovascular accidents, second malignancy and radionecrosis was detected.

SRS is an effective therapeutic option in the management of craniopharyngiomas located in the vicinity of the optic apparatus through providing a very steep dose-gradient outside the target volume, improving adjacent critical structure sparing. Utilization of this highly-sophisticated technology for optimal protection of visual and neuroendocrine functions has great implications on the quality of life, which is of utmost importance and a great concern for patients suffering from craniopharyngiomas, particularly for children. Improving the unwanted toxicity profile of patients with long-life expectancy, SRS therapy through rigid immobilization, accurate target and critical structure contouring with image-fusion, and set-up verification with Image Guided Radiation Therapy (IGRT) techniques have great potential to maximize improved treatment outcomes of the patients with long life expectancy.

\section{CONCLUSION}

Our study supports the use of LINAC-based SRS as a safe and effective management modality for patients with recurrent or residual craniopharyngiomas.

\section{REFERENCES}

1. Bunin GR, Surawicz TS, Witman PA, et al. The descriptive epidemiology of craniopharyngioma. J Neurosurg 89: 547-551, 1998.
2. Jane JA Jr, Laws ER. Craniopharyngioma. Pituitary 9: 323326, 2006.

3. Garrè ML, Cama A. Craniopharyngioma: modern concepts in pathogenesis and treatment. Curr Opin Pediatr 19: 471-479, 2007.

4. Durukan AH, Ceylan OM, Mutlu FM, et al. Ophthalmic findings and the importance of ophthalmic examination in the diagnosis of four patients with craniopharyngioma. Gulhane Med J 46: 175-179, 2004.

5. Dhellemmes P, Vinchon M. Radical resection for craniopharyngiomas in children: surgical technique and clinical results. J Pediatr Endocrinol Metab 19(Suppl 1): 329-335, 2006.

6. Tomita T, Bowman RM. Craniopharyngiomas in children: surgical experience at Children's Memorial Hospital. Childs Nerv Syst 21: 729-746, 2005.

7. Van Effenterre R, Boch AL. Craniopharyngioma in adults and children: a study of 122 surgical cases. J Neurosurg 97: 3-11, 2002.

8. Hoffman HJ, De Silva M, Humphreys RP, et al. Aggressive surgical management of craniopharyngiomas in children. J Neurosurg 76: 47-52, 1992.

9. Yasargil MG, Curcic M, Kis M, et al. Total removal of craniopharyngiomas. Approaches and long-term results in $144 \mathrm{pa}-$ tients. J Neurosurg 73: 3-11, 1990.

10. Fischer EG, Welch $\mathrm{K}$, Shillito J Jr, et al. Craniopharyngiomas in children. Long-term effects of conservative surgical procedures combined with radiation therapy. J Neurosurg 73: 534540, 1990.

11. Lober RM, Harsh GR 4th. A perspective on craniopharyngioma. World Neurosurg 79: 645-646, 2013.

12. Cama A, Ravegnani M, Piatelli G, et al. Conservative surgical approach in treatment strategy of craniopharyngioma: experience at a single institution in Italy. J Pediatr Endocrinol Metab 19(Suppl 1): 337-340, 2006.

13. Niranjan A, Kano H, Mathieu D, et al. Radiosurgery for craniopharyngioma. Int J Radiat Oncol Biol Phys 78: 64-71, 2010.

14. Minniti G, Esposito V, Amichetti M, Enrici RM. The role of fractionated radiotherapy and radiosurgery in the management of patients with craniopharyngioma. Neurosurg Rev 32: 1125132, 2009

15. Kobayashi T. Long-term results of gamma knife radiosurgery for 100 consecutive cases of craniopharyngioma and a treatment strategy. Prog Neurol Surg 22: 63-76, 2009.

16. Combs SE, Thilmann C, Huber PE, et al. Achievement of longterm local control in patients with craniopharyngiomas using high precision stereotactic radiotherapy. Cancer 109: 23082314, 2007.

17. Dincoglan F, Beyzadeoglu M, Sager O, et al. Evaluation of linear-accelerator based stereotactic radiosurgery in the management of meningiomas: a single center experience. J BUON 18: 717-722, 2013.

18. Dincoglan F, Sager O, Gamsiz H, et al. Stereotactic radiosurgery for intracranial tumors: a single center experience. Gulhane Med J 54: 190-198, 2012. 
19. Dincoglan F, Sager O, Gamsiz H, et al. Management of arteriovenous malformations by stereotactic radiosurgery: a single center experience. UHOD 22: 107-112, 2012.

20. Surenkok S, Sager O, Dincoglan F, et al. Stereotactic radiosurgery in pituitary adenomas: a single center experience. UHOD 22: 255-260, 2012.

21. Sirin S, Oysul K, Surenkok S, et al. Linear accelerator-based stereotactic radiosurgery in recurrent glioblastoma: a single center experience. Vojnosanit Pregl 68: 961-966, 2011.

22. Vinchon M, Dhellemmes P. Craniopharyngiomas in children: Recurrence, reoperation and outcome. Childs Nerv Syst 24: 211-217, 2008.

23. Minamida $Y$, Mikami T, Hashi K, Houkin K. Surgical management of the recurrence and regrowth of craniopharyngiomas. J Neurosurg 103: 224-232, 2005.

24. Caldarelli M, di Rocco C, Papacci F, Colosimo C Jr. Management of recurrent craniopharyngioma. Acta Neurochir (Wien) 140: 447-454, 1998

25. Laws ER Jr, Vance ML. Radiosurgery for pituitary tumors and craniopharyngiomas. Neurosurg Clin N Am 10: 327-336, 1999.

26. Kobayashi T, Kida Y, Mori Y, Haregawa T. Long-term results of gamma knife surgery for the treatment of craniopharingioma in 98 consecutive cases. J Neurosurg 103: 482-488, 2005.

27. Jeon C, Kim S, Shin HJ, et al. The therapeutic efficacy of fractionated radiotherapy and gamma-knife radiosurgery for craniopharyngiomas. J Clin Neurosci 18: 1621-1625, 2011.

28. Chung WY, Pan DHC, Shiau CY, et al. Gamma knife radiosurgery for craniopharyngiomas. J Neurosurg 93: 47-56, 2000.
39. Chiou SM, Lunsford LD, Niranjan A, et al. Stereotactic radiosurgery of residual or recurrent craniopharyngioma, after surgery, with or without radiation therapy. Neuro Oncol 3: 159166, 2001.

30. Ulfarsson E, Lindquist C, Roberts M, et al. Gamma knife radiosurgery for craniopharyngiomas: long-term results in the first Swedish patients. J Neurosurg 97: 613-622, 2002.

31. Gopalan R, Dassoulas K, Rainey J, et al. Evaluation of the role of Gamma Knife surgery in the treatment of craniopharyngiomas. Neurosurg Focus 24: E5, 2008.

32. Lee M, Kalani MY, Cheshier S, et al. Radiation therapy and CyberKnife radiosurgery in the management of craniopharyngiomas. Neurosurg Focus 24: E4, 2008.

\section{Correspondence}

Dr. Selçuk DEMIRAL

Gulhane Askeri Tıp Akademisi

Radyasyon Onkolojisi Anabilim Dalı

Gn. Tevfik Saglam Caddesi

06018, Etlik, Keçioren

ANKARA / TURKEY

Tel: (+90.312) 3044699

Fax: (+90.312) 3044680

e-mail: drs.demiral@hotmail.com 